EDWARD, D. G. FF. (1953). J. gen. Microbiol. 8, 256-262.

\title{
A Difference in Growth Requirements between Bacteria in the L-phase and Organisms of the Pleuropneumonia Group
}

\author{
BY D. G. FF. EDWARD \\ The Wellcome Research Laboratories, Beckenham, Kent
}

SUMMARY: Serum could be replaced in media for growing the L-phase of Proteus vulgaris by a phospholipid fraction from egg yolk and for growing the L-phase of Streptobacillus moniliformis by the addition of this fraction + bovine albumin. Organisms of the pleuropneumonia group grew in media in which serum was replaced by these materials, only with the further addition of cholesterol. The L-phase organisms thus differ in nutrient requirements from the pleuropneumonia group. They also differ in their requirements from the parent bacteria. Differences were noted in colonial appearances between the L-phase organisms studied and the organisms of the pleuropneumonia group.

It has been shown that many bacteria can exist in an L-phase which differs considerably in morphology and properties from the original bacilli (Klieneberger-Nobel, 1951; Dienes \& Weinberger, 1951). Morphological studies have suggested close similarities between bacteria in the L-phase and organisms of the pleuropneumonia group, and it has been stated that cultures of the two may be indistinguishable (Tulasne, 1951; Dienes \& Weinberger, 1951). However, in an investigation of the biological properties of the pleuropneumonia group significant differences in cultural appearances were noted between the L-phase of Streptobacillus moniliformis and organisms of the pleuropneumonia group (Edward, 1950). The relationship of the pleuropneumonia group of organisms to the L-phase of bacteria would seem to require further investigation in view of its importance in determining the taxonomic position of the pleuropneumonia-like organisms.

Although cultures of the L-phase of certain Gram-positive bacteria have been obtained on media not enriched with serum, the L-phases of Gramnegative bacteria have only been grown on media enriched with serum or ascitic fluid. All except the saprophytic members of the pleuropneumonia group require media similarly enriched. Cholesterol (or another sterol) has been shown to be an essential growth factor for the pleuropneumonia group; good growth was obtained on media in which serum was replaced by cholesterol + serum albumin or cholesterol + a phospholipid material from egg-yolk (Edward \& Fitzgerald, 1951). The examination of the L-phases of two Gramnegative bacteria, to find whether serum could be replaced in the medium by the same substances, has now revealed differences in growth requirements between them and organisms of the pleuropneumonia group. 


\section{MATERIALS AND METHODS}

Organisms. Three L-phase cultures were examined, namely, the L-phase of Proteus vulgaris (obtained from Dr L. Dienes), the L 1 organism (isolated in this laboratory from Streptobacillus moniliformis) and the L-phase of a strain of salmonella (isolated in this laboratory from a culture of salmonella provided by Dr L. Dienes). The L-phase of salmonella only grew with difficulty and it was impossible to examine its growth requirements. Comparative observations were also made on four members of the pleuropneumonia group: Asterococcus mycoides* and strains H17, C27 and C48 (Edward \& Fitzgerald. 1951).

Media and supplements. The media and the methods for preparing suspensions of cholesterol and of the acetone-insoluble lipid fraction of egg yolk (AIL) have been described previously (Edward, 1947; Edward \& Fitzgerald, 1951). The basal medium consisted of an ox heart infusion agar, to which was added $1 \%(\mathrm{w} / \mathrm{v})$ peptone and $10 \%(\mathrm{v} / \mathrm{v})$ yeast extract $(50 \mathrm{mg}$. Oxoid yeast extract $/ \mathrm{ml}$.). The AIL was further purified by two successive precipitations with acetone from solution in chloroform.

Inoculation. Suspensions of L-phase organisms for seeding on experimental media were obtained by washing the growth from a serum agar plate into broth. The organisms were sedimented by centrifugation in an angle centrifuge (c. 3500 r.p.m.) and resuspended in broth. Serial ten-fold dilutions of suspension were inoculated on segments of a plate. Before inoculation with the L-phase of Proteus vulgaris the medium was treated by spreading over its surface four drops of a solution of penicillin containing $10,000 \mathrm{units} / \mathrm{ml}$. to prevent reversion of the organism to the bacillary phase.

\section{RESULTS}

Nutritional requirements of $L$-phase and parent organisms

The results of the growth experiments are summarized in Table 1.

Strep. moniliformis. There was a trace of growth of the bacillus on the basal medium alone, which was not improved by adding $5 \mathrm{mg}$. bovine albumin (fraction V, Armour Laboratories)/ml. of medium, or cholesterol $(0 \cdot 1 \mathrm{mg} \cdot / \mathrm{ml}$.). Growth equal to that on a medium enriched with $10 \%(\mathrm{v} / \mathrm{v})$ horse serum was obtained by adding albumin + cholesterol. There was a moderately good growth on a medium containing AIL alone and growth about equal to that on serum agar on a medium containing AIL + albumin. Heilman (1941) showed that for growing Strep. moniliformis serum could be replaced in a fluid medium by starch. Dumhoff \& Duffy (1951) found dextrin and glycogen also capable of replacing serum; they suggested that these carbohydrates might act by neutralizing an inhibitory substance. Growth in the media containing carbohydrates was not as good as with serum.

L-phase of Strep. moniliformis (L1). The L-phase did not grow on the

* The organism causing contagious bovine pleuropneumonia; in previous papers it was erroneously called Asterococcus bovis. 
basal medium alone. It grew moderately well after the addition of bovine albumin $(5 \mathrm{mg} . / \mathrm{ml}$.); colonies were as numerous as on serum agar but were small and variable in size. There was also a moderate growth when AIL $(0.8 \mathrm{mg} . / \mathrm{ml}$.) was added to the basal medium. Growth equal to that on serum agar was obtained by adding bovine albumin + AIL. With a larger amount of

Table 1. Summary of results of growth on experimental media

\begin{tabular}{|c|c|c|c|c|c|c|c|}
\hline \multirow[b]{3}{*}{$\begin{array}{l}\text { Additions to } \\
\text { basal medium }\end{array}$} & \multicolumn{4}{|c|}{$\begin{array}{l}\text { Organisms of the } \\
\text { pleuropneumonia group }\end{array}$} & \multirow{2}{*}{\multicolumn{2}{|c|}{$\begin{array}{l}\text { L-phase } \\
\text { organisms }\end{array}$}} & \multirow{3}{*}{$\begin{array}{c}\text { Strepto- } \\
\text { bacillus } \\
\text { monili- } \\
\text { formis }\end{array}$} \\
\hline & \multirow[b]{2}{*}{$\begin{array}{c}\text { Strain } \\
\text { C27 }\end{array}$} & \multirow[b]{2}{*}{$\begin{array}{l}\text { Strain } \\
\text { C48 }\end{array}$} & \multirow[b]{2}{*}{$\begin{array}{l}\text { Strain } \\
\text { H17 }\end{array}$} & \multirow{2}{*}{$\begin{array}{l}\text { Astero- } \\
\text { coccus } \\
\text { mycoides }\end{array}$} & & & \\
\hline & & & & & $\begin{array}{l}\text { Proteus } \\
\text { 'L' }\end{array}$ & L1 & \\
\hline No addition & - & - & - & - & - & - & $\operatorname{tr}$ \\
\hline Bovine albumin ( $5 \mathrm{mg} . / \mathrm{ml}$.) & - & - & - & - & \pm & \pm & tr \\
\hline AIL $(0.8 \mathrm{mg} . / \mathrm{ml})$. & - & - & - & - & $\bar{t}$ & $\overline{ \pm}$ & \pm \\
\hline Albumin and AIL & - & - & - & - & + & $\overline{+}$ & $\overline{+}$ \\
\hline Cholesterol (0.1 mg./ml.) & $\operatorname{tr}$ & $\operatorname{tr}$ & - & - & - & - & tr \\
\hline Cholesterol and albumin & + & \pm & + & $\operatorname{tr}$ & $\operatorname{tr}$ & \pm & + \\
\hline Cholesterol and AIL & + & \pm & $+*$ & \pm & $\operatorname{tr}$ & \pm & \pm \\
\hline $\begin{array}{l}\text { Cholesterol, albumin } \\
\text { and AIL }\end{array}$ & + & $\overline{+}$ & + & $+*$ & \pm & \pm & $\overline{ \pm}$ \\
\hline
\end{tabular}

AIL (2 mg./ml.) growth was not as good. There was no growth in a medium to which cholesterol $(0 \cdot 1 \mathrm{mg} . / \mathrm{ml}$.) had been added. Cholesterol appeared to be inhibitory, because the addition of this amount of cholesterol to media containing bovine albumin alone, AIL alone or albumin + AIL usually gave poorer growth than in the corresponding medium without cholesterol.

Pr. vulgaris. This organism is known to be capable of growing on a chemically-defined medium containing only ammonia lactate, nicotinic acid and salts (Fildes, 1938).

L-phase of Pr. vulgaris (Proteus ' $L$ '). There was no growth on the basal medium alone. After the addition of bovine albumin $(5 \mathrm{mg} . / \mathrm{ml}$.) there was a moderate growth, the colonies varying in size and being smaller and less numerous than on serum agar. Growth about equal to that on serum agar was obtained by adding AIL $(0.8 \mathrm{mg} . / \mathrm{ml}$.). The organism failed to grow on a medium containing cholesterol $(0.1 \mathrm{mg} . / \mathrm{ml}$.), and the addition of cholesterol to media containing albumin alone, AIL alone, or albumin + AIL, gave growth which was poorer than on the corresponding medium without cholesterol.

\section{Nutrient requirements of the pleuropneumonia group of organisms}

The growth of organisms of the pleuropneumonia group on media containing cholesterol, bovine albumin and AIL, singly and in combination, has been tested previously (Edward \& Fitzgerald, 1951). Cholesterol was found to be a necessary medium component, and it appeared that both lipid and protein fractions of serum were concerned in its ability to promote growth. However, 
in a report published later Smith \& Morton (1951) reached a different conclusion regarding the nature of the growth factor in serum and ascitic fluid; they believed it to be a protein of low molecular weight or a large polypeptide. They obtained good growth of human genital strains by replacing the serum of their medium by a fraction of serum protein, without adding cholesterol or any lipid. In view of this divergence in results the experiments have been repeated in this laboratory. Confirmation has been obtained of failure to obtain growth on the basal medium used, unless cholesterol was added. Four strains of organisms of the pleuropneumonia group were tested. Two of the four grew poorly on a medium to which cholesterol $(0.1 \mathrm{mg} . / \mathrm{ml}$.) only had been added (Table 1 ). On a medium containing cholesterol + bovine albumin (5 mg./ml.) three strains grew well or moderately well, there being only a trace of growth with Asterococcus mycoides. All four strains gave a moderate or good growth on a medium containing cholesterol + AIL, and grew as well as on serum agar when cholesterol + albumin + AIL were incorporated in the medium. There was no growth with albumin alone, AIL alone or albumin + AIL without cholesterol.

Attempts were made to reconcile these findings with those of Smith \& Morton (1951). Fractions A and B, prepared from horse serum according to the methods they described, were incapable of adequately supporting the growth of pleuropneumonia-like organisms. Good growth was obtained using a commercially-available serum fraction (Bacto-PPLO serum fraction, Difco Laboratories), stated to be the same as Smith \& Morton's fraction A. From $100 \mathrm{ml}$. of this fraction $650 \mathrm{mg}$ of ether-soluble material was extracted by Hartley's method (1925). This material gave a strong Liebermann-Burchard reaction, and the original serum fraction was estimated to contain at least $150 \mathrm{mg}$. cholesterol $/ 100 \mathrm{ml}$. The serum fraction after extraction (protein fraction) no longer supported growth (Table 2). The ether-soluble material (lipid fraction) alone also failed to support growth, but good growth was obtained by adding both protein and lipid fractions to the medium.

There was moderately good growth on a medium containing cholesterol the

Table 2. Growth with Bacto-PPLO serum fraction after separation into its lipid and protein fractions

\begin{tabular}{|c|c|c|c|c|}
\hline \multirow[b]{2}{*}{ Additions to basal medium } & \multicolumn{4}{|c|}{$\begin{array}{l}\text { Strains of organisms of the } \\
\text { pleuropneumonia group }\end{array}$} \\
\hline & $\mathrm{C} 27$ & C. 48 & $\mathrm{H} 17$ & $\begin{array}{c}\text { Asterococcus } \\
\text { mycoides }\end{array}$ \\
\hline$O$ serum fraction $(1 \%)$ & + & + & + & \pm \\
\hline $\begin{array}{l}\text { ion after removal of lipids (protein } \\
(5 \%)\end{array}$ & - & - & - & - \\
\hline lipid fraction $(5 \%)$ & - & - & - & - \\
\hline ction $(5 \%)+$ lipid fraction $(5 \%)$ & + & + & + & \pm \\
\hline action $(2 \%)+$ cholesterol $(0 \cdot 1 \mathrm{mg} . / \mathrm{ml})$. & + & \pm & \pm & \pm \\
\hline $\operatorname{tion}(5 \%)+$ bovine albumin $(5 \mathrm{mg} . / \mathrm{ml})$. & + & + & + & tr \\
\hline
\end{tabular}

\footnotetext{
Bacto-PPLO serum fraction (1\%)

This fraction after removal of lipids (protein fraction) $(5 \%)$

Extracted lipid fraction ( $5 \%$ )

Protein fraction $(5 \%)+$ lipid fraction $(5 \%)$

Protein fraction $(2 \%)+$ cholesterol $(0 \cdot 1 \mathrm{mg} . / \mathrm{ml}$.)

Lipid fraction $(5 \%)+$ bovine albumin $(5 \mathrm{mg} . / \mathrm{ml}$.)
}

Protein and lipid fractions were reconstituted to the original volume of the material fractionated. 
protein fraction and on a medium containing the lipid fraction + bovine albumin. These results are in agreement with those obtained previously.

\section{DISCUSSION}

When an organism passes from the bacillary to the L-phase its growth requirements are radically changed. It becomes more exacting in its requirements so that subculture is always difficult; often attempts at subculture fail completely. Some aerobic bacteria, such as Salmonella spp., require low oxygen tensions in the L-phase. Media enriched with serum or ascitic fluid are needed to grow the L-phase of Gram-negative bacteria. In the present work a mixture of bovine albumin + a lipid fraction of egg yolk satisfactorily replaced serum for growing proteus ' $L$ ' and L1. Pr. vulgaris in the bacillary phase can grow on a chemically-defined medium containing ammonium lactate and nicotinic acid. The requirements of Streptobacillus moniliformis, the parent organism of L1, are more complex. It needed media enriched with serum, there being only a trace of growth on the basal medium alone. Serum could be replaced by bovine albumin + cholesterol; in this respect the organism differed from its L-phase. The more or less complete resistance of all L-phase organisms to the bacteriostatic action of penicillin would appear to reflect a fundamental difference in metabolism from that of the parent bacilli.

Oily globules are conspicuous in colonies of $\mathbf{L} 1$ examined microscopically. Partridge \& Klieneberger (1941) showed that they consisted largely of cholesterol. They were able to extract from the organisms an amount of cholesterol which represented about $16 \%$ of their dry weight. It appeared that the cholesterol was not synthesized by the organism but came from the medium. No growth occurred on a medium in which serum was replaced by cholesterol or cholesteryl palmitate. The L1 1 organism can grow in a medium enriched with bovine albumin instead of serum. Cholesterol could not be detected in bovine albumin by chemical estimation. Colonies of the second of two serial subcultures of $\mathrm{L} 1$ on this medium were examined microscopically after 6 days' incubation; no oily globules were seen. It thus appears that cholesterol is not needed for the growth of L1, but when present in the medium, tends to be accumulated or released from some solubilized form by the organism.

Morphological studies have tended to emphasize a close relationship between bacteria in the L-phase and organisms of the pleuropneumonia group (Dienes $\&$ Weinberger, 1951). All except the saprophytic species of the latter group require media enriched with serum or ascitic fluid. The serum can be replaced by cholesterol + bovine albumin + a phospholipid fraction (AIL) of egg yolk. It has not been possible in this laboratory to obtain growth except on media containing cholesterol or certain other sterols. On the other hand the two L-phase organisms studied grow well without the addition of cholesterol. These findings need to be confirmed by a study of the L-phase of other bacteria, but suggest that there may be important metabolic differences between the L-phase of bacteria and organisms of the pleuropneumonia group, the latter organisms requiring cholesterol while the $\mathrm{L}$-phase organisms either do not require it or are able to synthesize it. 
Similarities between bacteria in the L-phase and organisms of the pleuropneumonia group have possibly been over-emphasized. Fully-grown cultures of most L-phase organisms, according to published descriptions, differ considerably in their colonial appearances from organisms of the pleuropneumonia group. Colonies of adapted strains of the different species of the pleuropneumonia group are remarkably alike; they are circular in outline, circumscribed and translucent, with delicate surface markings and are usually small. In comparison, colonies of L 1 were more opaque and had coarser markings (Edward, 1950). In semi-solid and fluid medium the growth of L 1 was more like that of bacteria. The colonies of the L-phase of Proteus vulgaris and Salmonella sp. were also relatively opaque and had coarse surface markings, It would thus appear that a bacterium in the $\mathrm{L}$-phase tends to combine in the appearances of its growth the characters it possessed as a bacillus with the characters of a pleuropneumonia-like organism.

Smith \& Morton (1951) claimed that a protein of low molecular weight, capable of separation from whole serum, alone was responsible for the ability of serum to promote growth of organisms of the pleuropneumonia group. Their findings are thus in apparent conflict with the work which suggests that cholesterol is an essential growth factor. The experiments with cholesterol were repeated and confirmed previous findings. A commercially-available preparation of Smith \& Morton's fraction was found in fact to contain considerable amounts of lipid, including cholesterol. It may therefore be questioned whether the activity of the fractions examined by Smith \& Morton and believed by them to consist 'of proteinaceous material only', was not due to their containing lipid. In reporting a subsequent extension of their work Smith \& Morton (1952) made no reference to the evidence regarding cholesterol. It would have been of value to have had their explanation for the divergent experimental findings and to have learnt whether they had examined their active preparations for the presence of cholesterol, as we have done.

I wish to thank Dr L. Dienes for supplying me with cultures, Prof. B. C. J. G. Knight for his encouragement and advice and Dr A. J. Woiwod for cholesterol estimations.

\section{REFERENCES}

Dienes, L. \& Weinberger, H. J. (1951). The L forms of bacteria. Bact. Rev. 15, 245.

Dumofr, M. \& DufFY, C. E. (1951). The substitution of starch, glycogen and dextrin for natural body fluids in the cultivation of Streptobacillus moniliformis. J. Bact. $61,535$.

EDWARD, D. G. FF. (1947). A selective medium for pleuropneumonia-like organisms. J. gen. Microbiol. $1,238$.

Edward, D. G. FF. (1950). An investigation of the biological properties of organisms of the pleuropneumonia group, with suggestions regarding the identification of strains. J. gen. Microbiol. 4, 311.

Edward, D. G. FF. \& Fitzgerald, W. A. (1951). Cholesterol in the growth of organisms of the pleuropneumonia group. J. gen. Microbiol. 5, 576 .

Fildes, P. (1938). The growth of Proteus on ammonium lactate plus nicotinic acid. Brit. J. exp. Path. 19, 239. 
Hartley, P. (1925). Observations on the role of the ether-soluble constituents of serum in certain serological reactions. Brit. J. exp. Path. 6. 180.

Heilman, F. R. (1941). A study of Asterococcus muris (Streptobacillus moniliformis). II. Cultivation and biochemical studies. J. infect. Dis. 69, 45.

Kuifneberger-Nobel, E. (1951). Filtrable forms of bacteria. Bact. Rev. 15, 77.

Partridge, S. M. \& Klieneberger, E. (1941). Isolation of cholesterol from the oily droplets found in association with the L1 organism separated from Streptobacillus moniliformis. J. Path. Bact. 52, 219.

Smith, P. F. \& Mor'on, H. E. (1951). The separation and characterization of the growth factor in serum and ascitic fluid which is required by certain pleuropneumonia-like organisms. $J$. Bact. $61,395$.

Smith, P. F. \& Morton, H. E. (1952). Further characterisation of the protein factor required by certain pleuropneumonia-like organisms for growth in vitro. Arch. Biochem. 38, 23.

Tulasne, R. (1951). Les formes L des bactéries. Rev. Immunol., Paris, 15, 223.

(Received 18 August 1952) 